\title{
NON-FINANCIAL REPORTING REGARDING \\ NATURAL ENVIRONMENT IN PUBLIC \\ COMPANIES IN THE ENERGY, \\ FUEL AND GAS SECTOR IN 2019
}

Katarzyna Dembowska, MSc. (ORCID: 0000-0001-6471-6583) - Warsaw School of Economics

Correspondence address:

Nowiec Street 27, 80-293, Gdańsk, Poland

e-mail: kdembowska1@gmail.com

ABSTRACT: The article's objective is a presentation of the non-financial reporting practice in the scope of issues regarding the natural environment in public companies based on the example of the energy, fuel and gas sectors. The study covers WIG20, WIG30 and mWIG40 companies listed on the Warsaw Stock Exchange in 2019. The research method applied in the article is based on a case study. The article starts with the theoretical part regarding the disclosure of non-financial information. The second part presents non-financial reporting with special consideration given to the natural environment, based on public companies operating in the energy, fuel and gas sector.

KEYWORDS: non-financial reporting, corporate social responsibility, natural environment, Directive 2014/95/EU, public companies 


\section{Introduction}

In light of the concept of corporate social responsibility, the requirements for public companies in terms of access to information about them have been increasing for years - both in terms of information about their ongoing business activity as well as their commitment to environmental issues, human rights, or local communities. Currently, the financial statements prepared by economic entities are already insufficient. Therefore, an increasing number of enterprises is introducing corporate social responsibility rules in their business (Krzysztofek, 2016, p. 334-346).

Despite the fact that the first non-financial reports appeared in the 1980s (EY, 2016), changes in the scope of standards or verification of this reporting have appeared only in the last ten years. Furthermore, the development of reporting is also supported by the implementation of standards (e.g. GRI, IIRC) and regulatory changes (e.g. Directive 2014/95/EU) (Aluchna, 2018, p. 9-27).

Similarly to other scientific studies devoted to the issue of non-financial reporting, this article uses the terms 'non-financial reporting' and 'disclosure of non-financial information' interchangeably. It must be noted that the said terms are frequently limited to the information prepared in response to the regulations of Directive 2014/95/EU and the amended Accounting Act (Monciardini, 2016, p. 76-89). On the other hand, corporate social and environmental reporting and corporate sustainability reporting mean publication of information according to GRI standards (Hahn, Kuchnen,2013, p. 5-21; Tschopp, Huefner,2015, p. 565-577). Integrated reporting applies to a special for of reports combining three types of information (financial, environmental, social) and is most commonly prepared based on IIRC (Aluchna, 2018, p. 9-27).

The article's objective is to present the non-financial reporting practice in the scope of issues regarding the natural environment in public companies based on the example of the energy, fuel and gas sector. The study covers WIG20, WIG30 and mWIG40 companies listed on the Warsaw Stock Exchange in 2019. The research method applied in the article is based on a case study. The article starts with the theoretical part regarding the disclosure of non-financial information. The second part presents non-financial reporting with special consideration given to the natural environment, based on the example of public companies operating in the energy, fuel and gas sector. 


\section{Non-Financial Reporting}

In 2014, the European Parliament adopted Directive 2014/95/EU amending Directive 2013/34/EU as regards disclosure of non-financial and diversity information by certain large undertakings and groups (Ministerstwo Rozwoju, 2017). The subject directive was implemented in the Polish legal system by means of two legal acts:

- requirements in the scope of extended non-financial reporting - the amendment of the Accounting Act (Act of 15.12.2016 on Amendment of the Accounting Act, Journal of Laws of 2017, item 61),

- requirements in the scope of disclosure of information on the diversity policy as regards members of corporate bodies - the amendment of the Regulation on Current and Periodical Information (Regulation of the Minister of Finance of 25.05.2016 Amending the Regulation on Current and Periodical Information Disclosed by Issuers of Securities and Terms of Considering Information Required under the Laws of a Non-EU Member State Equivalent, Journal of Laws of 2016, item 860).

The said regulations imposed the obligation of extended non-financial reporting on the Public Interest Entities (PIE), i.e. (CSR, 2020):

- Enterprises preparing separate financial statements - having the form of commercial companies, limited joint-stock partnerships or such registered partnerships or limited partnerships whose all partners bearing unlimited liability are commercial companies or limited joint-stock partnerships or companies from other countries having a similar legal form, and if they exceed the following values in the financial year and prior financial year: average annual employment of 500 persons, total balance sheet assets amounting to PLN million 85 or net sales of goods for resale and products amounting to PLN 170 million,

- Enterprises preparing consolidated financial statements - having a legal as specified above, being the parent entities in the capital group if the capital exceeded the following values in the financial year and prior financial year: average annual employment of 500 persons and, less consolidation exclusions: total balance sheet assets amounting to PLN million 85 or net sales of goods for resale and products amounting to PLN 170 million (or: prior to consolidation exclusions: PLN 102 million or PLN 204 million, respectively).

Therefore, entities obliged to prepare extended non-financial reporting must prepare disclosures of non-financial information (as part of the report on operation) or a separate report devoted to it. Regardless of the selected form, such a document must contain, pursuant to Art. 49b, Para. 2 of the 
Accounting Act of 29 September 1994 and amended with the Act of 15 December 2016 (Journal of Laws of 2017, item 61):

- Business model - a brief description of the entity's business model,

- Indicators - key non-financial performance indicators related to the entity's operation,

- Policies - description of the policies applied by the entity in relation to social, employment, environmental issues as well as respecting human rights and counteracting corruption, and a description of results of the application of such policies,

- Procedures - description of due diligence procedures applied by the company under the policies referred to in the item above,

- Risks - description of material risks related to the entity's operation that could affect the issues referred to in the item "Policies", including risks related to the company's products or its relations with external surroundings, including contractors, and a description of risk management methods.

- Non-financial issues are presented in figure 1 below.

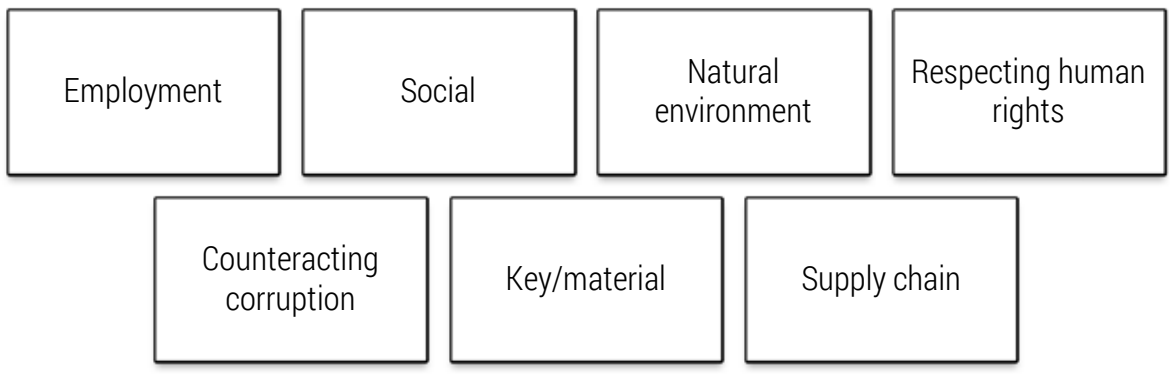

Figure 1. Non-Financial Issues

Source: own study based on: obligations resulting from Directive 2014/95/EU implemented in the Polish law by way of the Act of 15 December 2016 (Journal of Laws of 2017, item 61).

As regards non-financial employment issues, the following can be distinguished: issues of diversity in terms of age, sex, sexual orientation, religion, disability, such as issues of participation (participation and commitment of employees); terms and conditions of employment and work; relations with trade unions and respecting freedom of association; human capital management; career and recruitment management; training/education systems; occupational health and safety (Ministerstwo Rozwoju, 2017).

As regards social issues, the following can be distinguished: customer relations; monitoring of the satisfaction level, information on the possible impact of products on health and safety; responsible marketing and research; community relations (Ministerstwo Rozwoju, 2017). 
Regarding non-financial issues in the scope of counteracting corruption, the following can be distinguished: policies, procedures, management tools and systems preventing corruption and bribery; training and education in this scope; functioning of a whistleblower mechanism (Ministerstwo Rozwoju, 2017).

As regards non-financial issues in the scope of the natural environment, the following can be distinguished: issues of the natural environment, i.e. pollution control and prevention; impact on the environment resulting from use of energy; direct and indirect emissions to the atmosphere, protection of biodiversity and water sources; waste management; impact on the environment resulting from transport; impact on the environment resulting from use of services and products as well as their disposal (Ministerstwo Rozwoju, 2017).

As regards non-financial issues in the scope of respecting human rights, the following can be distinguished: company's expectations in terms of respecting human rights set for the employees and business partners; issues of human rights, including but not limited to the employees' rights, rights of persons employed for a definite term, children, native communities, owners of small farms, migrants, employees' families (Ministerstwo Rozwoju, 2017).

In terms of key/material non-financial issues, the company must examine the materiality of specific non-financial issues, which means: if the nonfinancial issue has a material impact on the company; if the company has a material impact on the given issue. The materiality of information must be assessed in context, i.e. the analysis must be carried out from the point of view of the company and its various groups of stakeholders (Ministerstwo Rozwoju, 2017).

As regards the supply chain, the Act refers to it as "relations with external surroundings, including contractors". This requires presenting at least the basic structure of the supply chain and the significance of non-financial information derived from it. Information that allows for an assessment of how and to what extent the supply chain affects the company's development, efficiency, and position and the impact exerted by it must be disclosed (Ministerstwo Rozwoju, 2017).

\section{Public Companies from the Energy, Fuel and Gas Sector in 2019 - Disclosure of Non-Financial Information}

The study analyses companies from the energy, fuel, and gas sector covered by WIG20, WIG30 and mIG40 indices and listed on the Warsaw Stock Exchange in 2019. The study analysed 6 companies reporting non-financial 
data: Enea Spółka Akcyjna (ENA), Grupa Lotos Spółka Akcyjna (LTS), PGE Polska Grupa Energetyczna Spółka Akcyjna (PGE), Polski Koncern Naftowy Orlen Spółka Akcyjna (PKN), Polskie Górnictwo Naftowe i Gazownictwo Spółka Akcyjna (PGN) and Tauron Polska Energia Spółka Akcyjna (TPE).

Table 1 below presents data regarding companies by capitalisation as of 31 December 2019. As one can see, the undisputed leader in terms of capitalisation is PKNORLEN (PLN 36,705.99 million), followed by PGNIG (PLN 25,008.55 million) and LOTOS (PLN 15,451.72 million). Furthermore, only the companies listed above paid out dividends for 2019. On the other hand, in terms of book value, three companies exceeding PLN 30 million can be differentiated: PGE (48,177.00), PKNORLEN (PLN 38,216.00 million) and PGNIG (PLN 37,757.00 million). Furthermore, if we look at the P/E ratio, i.e. the price-to-earnings ratio for the last 4 quarters, it turns out that the most attractive companies (the least overinvested) are ENEA (3.5), PGE (7.5) and PKNORLEN (8.3). As regards the P/BV ratio (Pomykalska, Pomykalski, 2017), i.e. the price-to-book ratio at the end of the last calendar quarter, one can see that all companies except for LOTOS have a very low company price.

Table 1. Public companies from the energy, fuel and gas sector in 2019

\begin{tabular}{|c|c|c|c|c|c|c|c|c|}
\hline \multirow{2}{*}{ Security name } & \multirow{2}{*}{$\begin{array}{l}\text { Shares } \\
\text { outstanding } \\
\text { (million) }\end{array}$} & \multicolumn{3}{|c|}{ Market capitalisation } & \multirow{2}{*}{$\begin{array}{l}\text { Book value } \\
\text { (PLN million) }\end{array}$} & \multirow{2}{*}{$\mathrm{P} / \mathrm{E}$} & \multirow{2}{*}{ P/BV } & \multirow{2}{*}{$\begin{array}{l}\text { Dividend } \\
\text { yield } \\
\text { (\%) }\end{array}$} \\
\hline & & PLN million & EUR million & $(\%)$ & & & & \\
\hline PKNORLEN & 427.71 & $36,705.99$ & $8,618.86$ & 6.67 & $38,216.00$ & 8.3 & 0.96 & 4.1 \\
\hline PGNIG & $5,778.31$ & $25,008.55$ & $5,872.21$ & 4.55 & $37,757.00$ & 14.5 & 0.66 & 2.5 \\
\hline LOTOS & 184.87 & $15,451.72$ & $3,628.19$ & 2.81 & $12,275.50$ & 17.2 & 1.26 & 3.6 \\
\hline PGE & $1,869.76$ & $14,883.30$ & $3,494.72$ & 2.70 & $48,711.00$ & 7.5 & 0.31 & --- \\
\hline ENEA & 441.44 & $3,494.02$ & 820.42 & 0.63 & $14,985.73$ & 3.5 & 0.23 & --- \\
\hline TAURONPE & $1,752.55$ & $2,874.18$ & 674.88 & 0.52 & $19,168.28$ & 13.9 & 0.15 & --- \\
\hline
\end{tabular}

Source: own study based on: https://www.gpw.pl/.

\section{Public Companies from the Energy, Fuel and Gas Sector in 2019 - Case Study}

The article discusses in most detail the non-financial issues related to the natural environment. The research method was based on a case study. In order to ensure study objectivity, a group of cases from the sale sector (energy, fuel and gas) for the same year was selected. The study's main objective is to verify how public companies from the energy, fuel and gas sector report non-financial data in the scope of the environment. Public companies 
operating in the energy, fuel and gas sector in 2019 are presented below in the context of non-financial reporting regarding the natural environment in alphabetical order.

\section{ENEA (7 pages)}

The report regarding issues related to the national environment contains 7 pages. The company's performance indicators related to the natural environment include, without limitation, fuel, water, and waste. In ENEA Group, the management of impact on the natural environment is regulated by the Integrated Quality, Environment and OHS System Policy. Specific companies have policies, procedures, instructions, and regulations adjusted to their specifics, obliging them to protect and use the environment in a sustainable manner and monitor and document specific impacts on the environment and obtained results of pro-environmental activities. Selected rules, e.g. determining procedures for generated waste, must also be followed by third-party companies performing works in areas belonging to and for the benefit of ENEA. Internal regulations include, first and foremost, the Code of Ethics of ENEA Group as well as Compliance Policy of ENEA Group, obliging the entities, among other things, to care for the natural environment and take all actions needed to protect it, regardless of the place and type of performed work, use the natural resources and energy reasonably, minimise pollution emission, use environmentally-friendly technology, prevent failures posing a threat to the environment, participate actively in ecological education actions (ENEA,2019).

\section{LOTOS (9 pages)}

The scale of operation of LOTOS Capital Group entails great responsibility for the impact on the environment and local communities neighbouring the oil refinery and employment establishments. To properly manage its impact and mitigate the associated risks, the organisation has developed "eco-responsibility" rules to be followed in its daily business. Rules of "EcoResponsibility": minimisation of the company's impact on the environment - in addition to compliance with the law, the company also tries to be proactive in environmental protection management; approach to protection of the natural environment extended with contractors and impact - the group takes responsibility for the impact on the environment exerted by the companies cooperating with it, only entities holding environmental protection licences and operate in compliance with the law in terms of waste management and storage of dangerous substances can be partners of the group; the company makes sure it complies with environmental protection requirements on 
every step by use of the most environmentally-friendly technical solutions, reasonable use of natural resources, preventing pollution already at the facility stage, observance of restrictive environmental standards; another important aspect for the company is increasing ecological awareness of its employees, the issues of environmental protection and its significance in the context of the local and global business of LOTOS Capital Group are presented by means of internal communication and trainings - the idea of such actions is also encouraging the employees to gain knowledge and implement pro-environmental actions in their private lives. Regarding performance indicators related to the natural environment, the following can be distinguished: greenhouse gas emission, production and use of energy, energy efficiency, raw material and material consumption, waste, water and wastewater, other emissions to the atmosphere (Lotos, 2019).

\section{PGE (42 pages)}

The report regarding issues related to the national environment consists of 42 pages. The PGE Group's targets include, without limitation: limiting pollution emission to the atmosphere, limiting pollution emission to wastewater, municipal waste management, limiting noise emission, animal protection. Regarding performance indicators related to the natural environment, PGE distinguishes, among other things: water, biodiversity, greenhouse gas emission, wastewater, waste. PGE Group is the largest electricity and heat producer in Poland. It is also the biggest green energy producer in the country. Thus, it actively pursues the climate policy targets, including $\mathrm{CO}_{2}$ emission reduction and gradual resignation from fossil fuels. In recent years, most conventional asset investments have been made to reduce the environmental impact of those entities, either directly through the construction of desulphurisation, denitrification, and dedusting installations or indirectly through modernisation that improves production efficiency. Due to consistent proenvironmental investments, the Group's power plants in Bełchatów, Turów, Opole, Dolna Odra and Rybnik gradually decrease the level of emission of nitrogen oxides, sulphur dioxide and dust to the atmosphere. The most important issues in the area of environmental protection include continuous improvement of qualifications and building of employees' awareness in the area of environmental protection, use of environmentally-friendly technology, effective use of fuels and natural resources, taking remediation and reclamation activities, supervising contractors' works, monitoring of the environmental impact of the Group's activities (PGE, 2019). 


\section{PGNIG (11.5 pages)}

The report regarding issues related to the national environment consists of 11.5 pages. Due to the complexity of processes performed in the specific segments, PGNIG impacts the environment in varying degrees and scales. PGNIG takes pro-environmental actions and initiatives adequate to the specifics of its business. The environmental area is regulated in PGNIG by two leading documents. The first one is the implemented QHSE Policy that is an expression of responsibility for the conducted business activity in the light of the global sustainable development challenges. The other document is the Sustainable Development Strategy of PGNiG Capital Group for 2017-202, the provisions of which emphasise the significance of the environmental area in the responsible functioning of the Group. The companies' business activities are inseparably related to interference with the surroundings, bearing in mind the potential negative impact on the environment and people. PGNiG aims to minimise its impact through analysis of environmental risks, continuous monitoring of the quality of air, surface and ground waters, soil surface, and application of state-of-the-art pro-environmental technologies. It must be noted that the Group described multiple performance indicators in relation to the environment (materials and raw materials used, energy use, water use, impact on biodiversity, direct $\mathrm{CO} 2$ emission, reduction of greenhouse gas emission, total wastewater quantity, waste management, closed economy). The most important issues in the area of environmental protection include continuous improvement of qualifications and building of employees' awareness in the area of environmental protection, use of environmentally-friendly technology, effective use of fuels and natural resources, taking remediation and reclamation activities, supervising contractors' works, monitoring of the environmental impact of the Group's activities (PGNIG, 2019).

\section{PKN ORLEN (9 pages)}

The report contains 9 pages regarding the environment. Limitation of the impact on the environment is one of the top priorities of ORLEN Group. The approach to management in environmental protection is based on the Corporate Social Responsibility rules and considering ecological criteria. The company aims to balance its targets in relation to its stakeholders and reports its environmental performance. The environmental targets are defined in the Integrated Environmental Policy adopted by PKN ORLEN. Responsibility for creating the environmental protection policy, promoting issues related to environmental protection, and developing a positive green image lies with the Environmental Protection Area. Its responsibilities also include monitoring, balancing and optimisation of greenhouse gas emissions as well as 
ensuring effective, compliant with the applicable laws, obtaining of gratuitous rights to carbon dioxide emission for installations covered by EU ETS, ensuring required ecological authorisations, conducting organisational and control activities aiming at compliance with the determined environmental standards, implementation and maintenance of the Leak Detection And Repair (LDAR) system in the Production Facility in Płock and PTA in Włocławek, assessing and payment environmental fees, consultation and substantive oversight over the scope and course of remediation works in the facilities of PKN ORLEN. Moreover, the key companies of ORLEN Group have Integrated Management Systems or Environmental Management System Policies in place, expressing their commitment to environmental protection, including prevention of pollution and other specific commitments material from the point of view of the operation of these entities. Environmental performance indicators distinguished by Orlen include, without limitation: waste, wastewater, water, emission to the atmosphere, low-emission economy and closed economy (PKN ORLEN, 2019).

\section{TAURON PE (12 pages)}

TAURON Group's Environmental Policy, adopted by the Company's Management Board in 2017, determines TAURON Capital Group's approach to environmental management, including the direction of its environmental activities and the rules it will follow in environmental matters. The environmental policy is a reference point based on which all activities of the TAURON Capital Group companies in the area of environmental protection and environmental management are assessed. The environmental policy documents the values and vision followed by TAURON Capital Group in the scope of impact on the natural environment. The main principle of the Environmental Policy is the limitation of both direct and indirect impact on the environment as well as effective communication ensuring understanding of the activities of TAURON Capital Group that could have an impact on the environment. TAURON Capital Group, according to the laws and administrative practice effective in the area of its operation, takes into consideration the needs related to environmental protection and acts in a manner contributing to the accomplishment of the broader goal, i.e. sustainable development, including but not limited to implementation of a closed economy. The most important environmental performance indicators distinguished by TAURON Capital Group include, among other things: the share of electricity, direct emission of greenhouse gases, waste. It must be noted that non-financial reporting in the scope of the environment is less clear for the readers than other reports (TAURON PE, 2019). 
The above summaries show non-financial reporting in public companies from the energy, fuel and gas sector in 2019. One can see that all analysed companies have: a description presented above depicts non-financial reporting in public companies from the energy, fuel and gas sector in 2019. Furthermore, one can see that all analysed companies have: a description of their business model, a description of policies concerning social issues, employment issues, the natural environment, respecting human rights and counteracting corruption. As regards performance indicators related to social, employment, environmental issues, and respecting human rights, all analysed companies have them. An exception is the performance indicator related to counteracting corruption that TAURONPE does not have.

\section{Summary}

Based on the conducted analysis, the following conclusions can be drawn: Implementation of legal regulations in the scope of reporting non-financial information (Directive 2014/95/EU) has had a significant impact on the increase in the scope of non-financial information disclosed by public companies. Information reporting is definitely better standardised, substance-focused and transparent, which makes it more reader-friendly.

Despite the fact that the analysed companies were covered by WIG20, WIG30 and mWIG40 indices and operated in the same sectors, they varied significantly in terms of capitalisation, from nearly PLN 37 million in the case of PKNORLEN to nearly PLN 3 million in the case of TAURON, which could have a significant effect on the substantive nature of the non-financial data (e.g. TAURON, as the only analysed company, did not have performance indicators regarding counteracting corruption).

All companies disclosed information on their business model, policies in relation to social issues, policies in relation to employment issues, policies in relation to the natural environment, policies in relation to respecting human rights and policies in relation to counteracting corruption. As regards performance indicators related to social, employment, environmental issues, as well as respecting human rights, all analysed companies have them.

In their non-financial reporting, all public companies operating in the energy, fuel and gas sector disclosed information in the scope of the building of employees' awareness of issues related to the natural environment, limitation and monitoring of the impact on the natural environment, use of environmentally-friendly technologies, use of natural resources and fuels, taking actions related to reclamation. 
The most transparent and reader-friendly reports containing non-financial data, i.e. best reporting practice, were presented by the following companies (in random order): PGNIG, LOTOS, PKNORLEN, PGE, i.e. companies with the highest capitalisation.

The least transparent and reader-friendly non-financial report was prepared by the company with the lowest capitalisation - TAURON.

\section{Reference}

Act of 15.12.2016 on Amendment of the Accounting Act, Journal of Laws of 2017, item 61.

Aluchna, M., Kytsyuk, I., Roszkowska-Menkes, M., 2018, Raportowanie społecznej odpowiedzialności biznesu. Przypadek spółek z WIG20, Studia i Prace Kolegium Zarządzania i Finansów / Szkoła Główna Handlowa, 170, 9-27.

Directive 2014/95/EU of the European Parliament and of the Council of 22 October 2014 amending Directive 2013/34/EU as regards disclosure of non-financial and diversity information by certain large undertakings and groups, L 330/1.

ENEA, 2019, https://raport2019.csr.enea.pl/pl/wplyw-na-srodowisko/ochronasrodowiska-w-strategii-grupy-enea/, [15.09.2021].

EY 2016, The Road to Reliable Nonfinancial Reporting, https://www.ey.com/Publication/ vwLUAssets/EY-ccass-road-to-reliable-nonfinancial-reporting/\$FILE/EYccass-road-to-reliable-nonfinancial-reporting.pdf, [15.09.2021].

GPW, 2021, https://www.gpw.pl/, [15.09.2021].

Hahn R., Kühnen M., 2013, Determinants of Sustainability Reporting: A Review of Results, Trends, Theory, and Opportunities in an Expanding Field of Research, "Journal of Cleaner Production", 59, 5-21.

Krzysztofek A., 2016, Dyrektywa 2014/95/UE oraz wynikające z niej zmiany, „Prace Naukowe Uniwersytetu Ekonomicznego we Wrocławiu", 450, 334-346.

Lotos, 2019, https://standardy.org.pl/wppsndrd/wp-content/uploads/2020/05/ LOTOS_2019_O_SJ.pdf, [15.09.2021].

Ministerstwo Rozwoju, Wydanie II poprawione, 2017, Raportowanie niefinansowe. Poradnik dla raportujących, pr. zbior. p. red. L. Anam, J. Kacprzak.

Monciardini, D., 2016, The 'Coalition of the Unlikely' Driving the EU Regulatory Process of NonFinancial Reporting, "Social and Environmental Accountability Journal", 36, 1, 76-89.

PGE, 2019, https://standardy.org.pl/wppsndrd/wp-content/uploads/2020/05/PGE _2019_S_SJ.pdf, [15.09.2021].

PGNIG, 2019, https://standardy.org.pl/wppsndrd/wp-content/uploads/2020/05/ PGNIG_2019_S_SJ.pdf, [15.09.2021].

PKNORLEN, 2019, https://standardy.org.pl/wppsndrd/wp-content/uploads/2020/ 05/PKNORLEN_2019_S_SJ.pdf, [15.09.2021].

Pomykalska B., Pomykalski P., 2017. Analiza finansowa przedsiębiorstwa Wskaźniki i decyzje w zarządzaniu, PWN, Warsaw, p. 131.

Regulation of the Minister of Finance of 25.05.2016 Amending the Regulation on Current and Periodical Information Disclosed by Issuers of Securities and Terms of 
Considering Information Required under the Laws of a Non-EU Member State Equivalent, Journal of Laws of 2016, item 860.

CSR, Społeczna Odpowiedzialność Biznesu (CSR) w czasach IV Rewolucji Przemysłowej, kontynuacja, etap X, 2020, Ewolucja raportowania niefinansowego w Polsce. Analiza raportów niefinansowych za 2019 rok spółek notowanych na Giełdzie Papierów Wartościowych w Warszawie, „Kolegium Zarządzania i Finansów, Katedra Teorii Zarządzania, Centrum Badań nad Odpowiedzialnym Biznesem SGH", dr hab., prof. SGH Rafał Mrówka.

TAURONPE, 2019, https://standardy.org.pl/wppsndrd/wp-content/uploads/2020/ 06/TAURONPE_2019_S_SJ.pdf, [15.09.2021].

Tschopp D., Huefner R., 2015, Comparing the Evolution of CSR Reporting to that of Financial Reporting, "Journal of Business Ethics”, 127, 565-577. 